International Journal of Instruction

e-ISSN: 1308-1470 • www.e-iji.net
July $2019 \bullet$ Vol.12, No.3

p-ISSN: 1694-609X

pp. 633-650

Received: 14/12/2018

Revision: 20/04/2019

Accepted: 24/04/2019

OnlineFirst: 12/05/2019

\title{
The Education Values of Indonesian Teachers: Origin, Importance, and Its Impact on Their Teaching
}

\section{Suyatno}

Universitas Ahmad Dahlan, Yogyakarta, Indonesia, suyatno@pgsd.uad.ac.id

\section{Dholina Inang Pambudi}

Universitas Ahmad Dahlan, Yogyakarta, Indonesia,dholina.pambudi@pgsd.uad.ac.id

Asih Mardati

Universitas Ahmad Dahlan, Yogyakarta, Indonesia, asih.mardati@pgsd.uad.ac.id

\section{Wantini}

Universitas Ahmad Dahlan, Yogyakarta, Indonesia,wantini@mpai.uad.ac.id

\section{Eka Nuraini}

Akademi Manajemen Belitung, Indonesia,ekanuraini@amb.ac.id

\section{Yoyo}

Universitas Ahmad Dahlan, Yogyakarta, Indonesia,yoyo@bsa.uad.ac.id

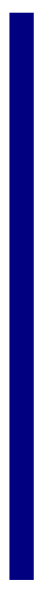

This research aims to reveal the education values of teachers; where they recognized the values, the importance of the values for teachers in performing their duties, the effects on their teaching methods, and how well the undergraduate program has equipped them with the competence of values education. Qualitative interviews were conducted with 56 teachers. The results identified two categories of people, namely ones with positive experience-based and ones with negative experience-based values. Furthermore, the following four important findings were obtained on analyzing these categories: (1) value is an important factor for teachers in carrying out their professional duties in both categories; (2) the majority of teachers in the positive experience-based category recognize the values from their mothers, literary works, and few from their former teachers, while teachers in the other category obtain values from their teachers and a few from their family life; (3) the way teachers recognize value impacts on how they teach it to students; (4) the undergraduate education experienced by prospective teachers at the university does not provide the needed competency in teaching values to the students.

Keywords: education values, Indonesian teachers, positive and negative experiencebased values, junior high school students, teaching

Citation: Suyatno, Pambudi, D. I., Mardati, A., Wantini, Nuraini, E., \& Yoyo. (2019). The Education Values of Indonesian Teachers: Origin, Importance, and Its Impact on Their Teaching. International Journal of Instruction, 12(3), 633-650. https://doi.org/10.29333/iji.2019.12338a 


\section{INTRODUCTION}

The teaching of values in education has recently become an interesting issue in various countries, including Indonesia. According to Tillman (2004), in 2004, 20 educators with a great concern for values gathered from five continents and gave recommendations on how to make universal values grow in every child. This meeting gave birth to a program called Living Values Education, which was an approach on how to grow values in everyday life. Also, Arthur et al. (2015) examined values in education among schools in the United Kingdom. The results indicated that lately, there has been a consensus that values such as honesty, open minded, respect, and gratitude are needed as part of the solutions to the various problems in the society. Furthermore, when children are raised up with those values, it has positive impacts on school achievement, welfare, and professionalism at work.

In Indonesia, the values in education have never been left behind in the curriculum renewal agenda. The current curriculum known as the 2013 Curriculum or K-13, has it as the main core during implementation. In it, it is specified that every learning process in the classroom should lead to the formation of values in students, both spiritual (core competencies 1) and social (core competencies 2). These are the basic human needs for improving and developing to be a complete human being. Furthermore, Hattie (2003); DEST (2008); Benninga, Berkowitz, Kuehn, \& Smith (2006); Lovat, Clement, Dally, \& Toomey (2010) state that values education can have a positive impact on students, teachers, and the school as a whole.

A study conducted by Abramauskienè (2015) with some students from the Faculty of Education in University of Lithuania revealed that the students have strong nationalist feelings caused by being proud of their nationality, religions, traditions and customs, history of the country, language, architectural monuments, and the beautiful nature. Furthermore, a study by Brady (2011) identified 4 approaches of values education in Australian schools, namely: 1) the trait approach, 2) values clarification, 3) the cognitive developmental approach, and 4) the role-play. Those findings can be used as an alternative for teachers in equipping themselves with values education. In contrast, a study conducted by Purpel (2011) states that the studies of values education have exposed school failures in teaching values to their students.

Also, Suyatno et al. (2019) conducted a research focusing on how teachers instill values in their students and the most important values for students at the junior high school level. The results showed that the two most important values are faith (iman and taqwa) and noble character. It also identified five strategies used by teachers to instill values in the students, which are the habituation of values, the role models of values, the internalization of values, the integration of values in subjects, and the civilization of values.

\section{Problem Statement}

In last two decades, many efforts had been done in order to improve the quality of values education; such as establishing various education programs to promote the values to students (Dalton \& Crosby, 2010). Education system in Singapore, Australia, 
Germany, and New Zealand also has paid a serious attention to the values education (Singh, 2001). India, Australia, and Singapore emphasize the values education more on curriculum and syllabus (Singh, 2001). To perform the success of values education at school, the capability of teachers in presenting the values plays a big role from which the students can easily accept and understand the values. Teachers are required to be a role model of the values, focus on the students' strengths, facilitate their social development. Not only teachers, administrative members of the school are also required to support the relation among the students and involve the parents in many programs conducted by the school (Brown et al., 2006).

Even though many efforts and implementations of values education have been taking place for long and serious, there are still many problems found on the implementation of the values education at school. Many previous researches indicate how important the teachers' competence in the values education. As stated by Hadi (2015), teachers in school still have inadequate skills to integrate the values to their learning process. It is line with the research results of Lovat et al. (2009) which show that the main parameter required in the values education is competent teachers who are able to formulate and teach the values to the students comprehensively.

\section{Research Questions}

In detail, these are the research questions: 1) How do teachers recognize the values? 2) What is the importance of the values for teachers in performing their duties? 3) What are the effects on their teaching methods? 4) How well is the undergraduate program equipped the teachers with a competence of values education implementation? Comprehending the answers of those four questions will be so much useful for the education policy makers to review and evaluate the programs of teachers' professionalism development either in the form of training or curriculum revision in the under-graduate program.

\section{LITERATURE REVIEW}

\section{The Urgency of Values Education}

Values are very important in human lives. According to Arthur (2003), value is a set of interlocking personal principles that guide a person to take an action. It describes a person and whether that person is good or bad. In line with that, Lockwood (2009) defines it as a criterion that someone uses in making judgments of an object, person, or action.

Values could develop along with life experiences. McLaughlin \& Halstead (1999) explain that values are subjective and influenced by personal experience and emotions. And talking about their importance, Bennett \& Delattre (2011) state that values should be a major concern in learning at school. Moreover, values education is the core of the philosophy of education (Carr, 2008; Salls, 2007; Wren, 2008). Also, according to Berkowitz \& Bier (2005), it could not only be taught through specific curriculum or programs in the classrooms but could also be instilled through experiences during school activities. 
Basically, teaching is a profession which is always in constant touch with values. DEST (2008) reveals that values education could make positive changes for teachers in carrying out their duties, especially in building relationships and communication with students. A research by Metzger and Wu (2008) reveals that the best teachers who can teach effectively are those who are able to transmit to others values such as perseverance, caring, and commitment.

Values education is also very important for students as various studies have shown some positive relationship between both. According to Benninga et al., (2006); Brooks \& McCarthy (2001); and Ferguson (1999), values education could improve the students' self-management ability and develop good relationships with other peers and the teachers. This is supported by a study by Tirri (2010) which states that values are the most obvious expression of emotions in students. The core of teaching is a moral process where the teacher's job is to shape and equip students' understanding to be better persons. Until this is achieved, schools should make values education their mission. Also, Connors (2002) sees education as an effective tool that can make students be more valuable people and according to Capel (2015), the learning process at schools could be a medium of values transfer.

\section{The Teachers' Role in Values Education}

Teaching is one of the professions that have to do with instilling values in students. Teachers live based on values because of their position as role models. According to O'Sullivan (2005), reflecting on the teachers' beliefs and values could have impacts on their behavior and practice in the classrooms. In a study conducted by Lovat (2007a), it was discovered that teachers who use a values-based pedagogical approach have a positive impact on students. Also, Hattie (2003), Lovat (2007b), and Williams (2000) prove that the teachers' roles in the classroom are the most important factors in students learning.

Furthermore, Brady (2011) explains that there are 8 values needed by teachers in implementing a learning approach. These are as follows:1) demonstrating sensitivity, 2) practicing tolerance, 3) challenging egocentrism, 4) observing neutrality, 5) sustaining relationships, 6) scaffolding learning, 7) encouraging student expression, and 8) promoting a supportive context for learning. All these are very important for teachers if values education must be successful. Also, the challenge in implementing values education is the inability of teachers to create conducive classroom environments. Therefore, students would feel free to express ideas, opinions, feelings, and also be tolerant of the opinions of others.

In carrying out an effective learning process, teachers need to have values in the learning process. According to Chong and Cheah (2009), there are six important values that should be possessed by a teacher and these are 1) Values that have to do with the belief that all students can learn well, as every child has their own potential and though there may be some weaknesses in certain areas, they are good in other fields. Therefore, teachers need to do everything possible to help students; 2) Care and focus on all students in the class. This is in accordance with the statement of Eisner (2002), that 
teaching, in essence, is caring for the students. 3) There should be respect for diversity. This is based on the fact that students come from different economic, religious, racial, linguistical, and ethnical backgrounds and are different even in terms of academic ability. Therefore, teachers need to respect these differences and accept them wholeheartedly. And according to Banks et al., (2005), these diversities could become effective learning tools for students to learn about and understand each other. 4) Having a high commitment and dedication. A commitment to assisting students is the key to becoming a professional teacher. Bransford, et al. (2005) state that teachers must be committed to preparing students to be able to participate in democratic societies. 5) Value of collaboration, team spirit, and sharing. The role of tripusat education, which includes schools, homes, and communities is very important in achieving educational success. 6) A strong desire for continuous learning and innovation. Darling-Hammond $\&$ Bransford (2005) buttress the fact that teachers cannot stop learning. They are required to be lifelong learners.

\section{Improving Values Competence in Teacher Education and Training Programs}

The importance of values for teachers requires that institutions place the right portion of the competence in teaching it. A study by Mergler \& Spooner-Lane (2012) states that values education is a way of reconstructing education in Australia and that this can be implemented both implicitly in terms of including it in the formal curriculum and explicitly through discussion and debate. In this way, it is possible for students and teachers in schools to explore and improve their values.

In Indonesia, the main focus should be on LPTK or teacher training institutions. Lovat et al. (2011) suggest that teacher education has to prioritize a more holistic view and provide a sufficient space for prospective teachers to get the skills to be effective in teaching values. A study conducted by Brady (2011) suggested four approaches to implementing values education in Australian schools, which are: 1) the trait approach. This focuses on developing the predetermined values observed through the direct teaching and moral biography; 2) clarification values. This focuses on the process carried out by the teacher to make students aware of their personal values; 3) the cognitive developmental approach which focuses on the efforts to improve students' moral reasoning abilities; 4) role play. This focuses on forming the awareness through acting and painting it in a scenario.

A study conducted by Mergler (2008), titled Making The Implicit Explicit: Values and Morals In Queensland Teacher Education, shows that in the College of Teachers in Queensland, some professional standards are formulated about the expectations of teachers from their profession and these standards are grouped into three main aspects, which are teaching and learning, professional growth, and professional relations. Each aspect is further developed into three areas, i.e. 1) what teachers do (practice), 2) what teachers know (knowledge) and 3) what teachers are committed to (values). From this research, it is obvious that values are one of the important aspects in the development of professionalism in teaching. 
Furthermore, Watt \& Richardson (2004) conducted a survey on 1,140 first-year students with majors in teacher education. This study was aimed at determining the factors that influence students to choose teaching as a profession. The result shows that the most influential factors are: 1) teaching is a laden-value profession, 2) opportunities to prepare students' future and contribute to society and 3) desire to work with children.

In another similar research, O'Sullivan (2005) worked on the reasons why pre-service teachers choose the profession as educators. The study revealed that the strongest reason is that they wanted to make a difference in the students' lives, to help them to grow and to become aware of their abilities, needs, and life goals. Also, Carr (2004), Lunenberg et al. (2007) and Gellel (2010) revealed that one of the ways that scholarship and LPTK can help is by creating practice communities that can connect the pre-service teachers with those already in the profession, as well as the students and the wider school community.

\section{METHOD}

\section{Research Design}

This research is a qualitative descriptive study. The main sources of data are the experiences of the participants in recognizing values, their opinions about the importance of carrying out their profession, and their experience in instilling values in students.

\section{Participants}

The total population of this study was 413 teachers spread across 5 sub-districts in Belitung Regency. In determining this sample size, the researchers asked for the assistance of the Education Office of Belitung Regency to choose the teachers through the purposive sampling technique. The Head of the Belitung District Education Office then sent letters to all 28 junior high schools in the Belitung district, and each school was asked to send 2 teachers based on some conditions. Therefore, the participants were made of 56 teachers from 28 junior high schools in Belitung Regency, both public and private. The demographic data of these people is shown in Table 1. 
Table 1

Demographics of Research Informants

\begin{tabular}{lll}
\hline Demographic & Number & Percent (\%) \\
\hline Gender & & \\
\hline Male & 19 & 33.93 \\
Female & 37 & 66.07 \\
\hline Age (in years) & & \\
\hline $20-30$ & 10 & 17.86 \\
$31-40$ & 28 & 50.00 \\
$41-50$ & 12 & 21.43 \\
$51-60$ & 6 & 10.71 \\
\hline Educational Level & & \\
\hline S1 & 48 & 85.71 \\
S2 & 8 & 14.29 \\
\hline Teaching Experiences (in years) & & \\
\hline $0-10$ & 22 & 39.29 \\
$11-20$ & 23 & 41.07 \\
$21-30$ & 11 & 19.64 \\
\hline
\end{tabular}

Technique of Collecting and Data Analysis

The data for this study was collected through semi-structured interviews. To lead the researchers obtaining the data needed, the researchers set an interview guidance containing a list of questions and topics for the interviewees. The interview guidance was developed based on the theoretical framework that had been presented earlier. To ensure the validity, the research instrument had been consulted to expert judgements. The researcher invited two expert judgements (expert judgement of learning and expert judgement of values). In accordance with their suggestions, the design of the instrument was then revised and used in the process of obtaining the data in the field.

The researcher was assisted by two research assistants that helped in recording answers from the participants in a notebook and video. Upon completion, the researcher checked to be sure that the collected data is valid. According to Creswell (2008) and Liamputtong (2009), analyzing the data of this kind of study should begin by transcribing the interviews and re-reading the results. This was followed by data reduction done by selecting and sorting the data in accordance with the research questions. Then, the results are coded in order to break the data down before it was used (Doglas, 2003).

\section{FINDINGS}

The data coding results are used to create two broad categories of data which are the positive experience-based values and the negative experience-based values. The data in the positive experience-based values are those from teachers who have positive experiences (pleasant, optimistic, and uplifting) in recognizing values while those in the negative experience-based values category are data from teachers with negative experiences ( $\mathrm{sad}$, humiliated, and pessimistic) in recognizing values. Data from each category are then broken down into the more detailed units from which the values are 
recognized, that is, the importance of value in carrying out their duties with the experience in teaching values to the students.

\section{Positive Experience-Based Values}

\section{How Teachers Recognize Values}

The interview results show that the majority of teachers in this category recognize values from their mothers, literary works, and their own teachers. The response to the interview from AL, a science teacher from SMP N 3 Sijuk, is as follows:

Interviewer : How did you recognize values?

AL : I got values from my mother. She is a very simple person, who only attended junior high school. But she is an honest person in all her dealings and all her children show this value.

For the same question, RA, an Indonesian Language Teacher from SMP N 2 Tanjung Pandan gave the following response:

I learned most values from my mother. She is a sincere and wise woman who does not like bothering other people. She is simple and always patient with her children and people in general. I learned being sincere from her.

Also, RP (BK Teacher from SMP N 4 Tanjung Pandan) revealed that: "... I learned honesty from my mother. Aside from that, she is patient, a sincere person, loving, always wants to help others, and does not show prejudice towards anyone..." Some of the teachers also recognize values from literary works like novels. This is the response of EW:

Interviewer : How did you recognize values?

EW : I recognized value for the first time when I read the novel Laskar Pelangi, even though I did not know it was called value at that time. I learned to work hard, never give up, and to be sincere in carrying out my professional duties.

Also, MU (English Teacher from SMP N 4 Tanjung Pandan) gave this response, "I learned value from the Laskar Pelangi novel. The values contained in it are about the life struggles that bring success". Furthermore, SL, an Indonesian Language Teacher from SMP N 4 Tanjung Pandan said, "I learned value from a novel titled Sengsara Membawa Nikmat. It teaches hard work as the major way to be happy in life..."

Aside from the two factors already identified, some recognize values from their school teachers. The response of YM, a Mathematics Teacher from SMPN 2 Sijuk, is as follows:

At that time, I went to school while do selling. One teacher knew and asked why I do it even though my parents were a capable family. I replied that I really enjoyed selling and from it I could practice independently. My teacher said that I was great. He advised that you could do selling but you should not miss the 
subjects. From that experience I learned about the importance of respecting others.

\section{The Importance of Value for Teachers}

As earlier described, having values is very important for teachers individually and as educators. The values possessed by a teacher which are used as guidelines in their daily life can also be used during teaching. The results from the interviews show that there are no fundamental differences regarding the importance of values for teachers. In both categories, the teachers assume that value is important for effectively carrying out their duties. This is shown in the response of AL.

Interviewer: What is the importance of value to you as a teacher?

AL : For me, teaching is not just about transferring knowledge, but also about instilling students with good attitudes such as honesty, discipline, obedience to worship and so on. And with the values that I possess, I can be a role model to my students.

And this is what FL gave as a response to the same question.

Value is something that should be fought for. For example, I grew up in a family where my parents were very concerned about religious values. It impacted the way I teach because I always prioritize these religious values while in the classroom. One certain thing is that if it's time to worship, all the students must do it.

\section{How Teachers Teach Values to Students}

The way teachers teach values to their students is influenced by some factors and one of such is the way they recognize it. The majority of teachers in this category tend to instill values in their students based on pedagogical principles, by sharing empathy, caring, and trying to be a role model to those students.

Interviewer : How do you instill values in your students?

RA : Well, there are many ways. But in my opinion, the most important thing is that, as teachers, we must become examples to those students both with our words and actions.

Also, ND, a Science teacher from SMP N 2 Sijuk said this to the same question.

Interviewer : How do you instill values in your students?

ND : I always try to act as an example to my students. I learned the act of dedication from one of my high school teachers. This person really inspired me to do better academically.

Interviewer : In your opinion, what kind of teacher inspires others?

ND : A teacher who inspires is the one who is able to make students have directions for tomorrow and know what they want in life. 
And apart from experience, they also instill values in students based on training sessions attended. A teacher of social studies (PA, SMP N 7 Tanjung Pandan) revealed that:

I teach values to my students based on training sessions that I often attended, both in formal and informal settings. I pass some of those things learned to the students, and also through extracurricular activities.

An educator must be a lifelong learner. Therefore, a teacher must be diligent in participating in training to gain more competency. However, some stated that the opportunity to participate in such training sessions was not available and so have not attended one. This is the response given by Y, an Islamic Education teacher in SMP N 2 Tanjung Pandan:

Teachers in large schools and those in the cities can easily go for training but that is not the case for those in smaller schools and far from the cities"

\section{Negative Experience-Based Values}

\section{How Teachers Recognize Values}

The majority of teachers in this category recognize values from their former teachers and a few from their family members. SL, an English Language Teacher from SMP N 3 Tanjung Pandan gave this response:

Interviewer : How did you recognize values?

SL $\quad$ : I was once ordered by a teacher to attend every class but I misinterpreted it. The first class I attended, I copied all the students' names and submitted it to the teacher. Then he said, "Ah bange kamu ini" (Belitung language, meaning "you are stupid"). I felt embarrassed and insecure from that moment because the teacher did not appreciate what I had done.

Although the incident made SL feel embarrassed and insecure, they were able to learn respect as a value. Another teacher, NE said this:

I had a small stature and whenever we were having competitions, my teacher always ignored me because I was considered not to be competent. I felt hurt and insecure but it taught me the importance of hard work in order to gain success.

And just like SL, NE recognized values through the attitude shown by a former teacher who always denied him from participating in competitions because people generally look down on his abilities.

These show that some teachers recognize values from the events that make them feel inferior, sad, and disappointed. This is an indication that such negative learning environments still exist in some schools where teachers bully students, operate with discriminatory rules, and so on. Some teachers, like LS, teaching at SMP N 4 Tanjung Pandan, recognize values through family life experiences.

Interviewer : How did you recognize values? 
When I was young, I was always competing with my brother and I always ended up on the losing side. So I worked harder so as to show people that I can succeed. And I am a teacher today.

The response given by LS is an indication that values can be learned through experiences of loss.

\section{The Importance of Values for Teachers}

The researchers could not find a fundamental difference in the importance of values in both categories. All teachers are of the opinion that values are important in carrying out their professional duties. According to NE, through the values he had was able to become a professional teacher.

I am still standing here as a teacher because I fought for my religious values. Teaching is worship.

\section{How Teachers Teach Values to Students}

In contrast to the teachers in the positive experience-based values category, those in the second category believe that teaching values to students needs to be done through strict punishment and discipline. A teacher, HS, gave this response:

Interviewer : How do you instill values in your students?

HS : Students should be disciplined for coming late to school, for example, so as to avoid such act.

Interviewer : How important is punishment in forming discipline in students?

HS : Punishment is very important as, without it, there is no discipline.

In line with this, a BK teacher named AA stated that "It is important to implement reward and punishment. Students should be rewarded for doing good and be punished if found doing wrong things". For AA, punishing students is one of the ways to bring out honesty in students.

\section{How Well the Undergraduate Program Equipped the Values Education Competence to Teachers}

Teachers from both positive and negative experience based-values category have the same ideas on how undergraduate programs at university equipped the teachers with the competence of values education. LS, a teacher from negative based-values category, stated that:

In formal, the lecturing activities experienced by me does not equip the students enough; especially me in term of my capability on the values education. I learned from my own experiences, mainly on activities that I have done outside the campus. 
In line with LS, PA, a teacher from positive experience based-values category also asserted that during her study at university, she had not focused yet on becoming a teacher and role model for her students in the future. She expressed:

During my study at university, i did not get a lot of explanations on the role of teachers in assisting the students' characters. As I was a prospective teacher of Social Science, my focus is mainly on studying the lecturing materials of Social Science. My competence of teaching the values to the students now is probably gained through many training programs which were conducted by either education authority or any other informal training programs.

Most of the research subjects stated that their study at undergraduate degree does not completely give much preparation to the prospective teachers to be an agent of values for their students. As expressed by those two teachers, LS and PA, they did not get enough preparation to be a values educator.

\section{DISCUSSION}

There are four important findings obtained from this study as described in the previous section. Firstly, value is important for teachers in both categories in carrying out their profession. Secondly, the majority of teachers in the positive experience-based values category recognize the value from their mothers, literary works, and few from their former teachers. Meanwhile, the majority of those in the negative experience-based values category recognize values from their former teachers and a few through family life. Thirdly, the way teachers in the positive experience-based values category instill values in the students through pedagogic ways like directing, guiding, sharing experiences, empathy, caring, and being role models, while those in the opposite category choose the way of strict discipline and applying the reward and punishment method to students. And fourthly, the undergraduate education experienced by prospective teachers does not bring competency in teaching value to students. These four topics will be described proportionally one by one in the following paragraphs.

The majority of teachers from both categories confirm the importance of values in successfully carrying out their profession. Teachers with certain values tend to be able to carry out their profession wholeheartedly. Therefore, they can create a better learning environment. According to DEST (2008), value education can make positive changes for teachers in performing their duties, especially in building relationships and communication with students. And the findings of Eisner (2002) reveal that teaching is essentially the practice of caring for students who have been verified in this study. Likewise, the research of Chong and Cheah (2009) states that in order to be successful in carrying out their duties, teachers need to have values of commitment and dedication. Also, according to Metzger and Wu (2008), the best teachers are also effective in transmitting values such as perseverance, caring, and commitment to others. Furthermore, teachers in both categories recognize values which means that the growth values in a person are much influenced by the experiences with people closest to them. This finding is in line with the expression that values are caught, and not taught. 
Teachers in the positive experience-based values category tend to teach values to students based on pedagogical elements by guiding students, discussing, sharing values, and even trying to be role models for the students. This may be due to their positive experience of values. Lovat (2007a) found that teachers who use a pedagogical approach can make a positive difference in a student's learning process and life.

Conversely, teachers who have negative experience-based values tend to teach values to their students through strict discipline and punishment. Also, they might be inspired by their learning experiences just like the story of the teacher who learns the value of competition with the brother and always feels defeated. From this, he believes that any working partner he has is a competitor who must be defeated.

The results of this study also show that during college education, teachers from both categories did not gain sufficient experience and competence to teach values to their students. This is in line with the study conducted by Gellel (2010) which explained that the experiences gained by prospective teachers during their studies were not enough and then suggested that pre-service teacher education practice should be created through "short residential periods, social activities, and discussion groups." Therefore, LPTK needs to review both the curriculum and the educational practices implemented. Furthermore, according to Gellel, these teachers should be given the opportunity to reflect, obtain stories, and describe concepts that illustrate the daily reality of teachers and schools.

The programs towards improving teachers' competency should determine teachers to develop contexts that can support the success of student learning at school (DarlingHammond \& Bransford, 2005). The results of this study are also supported by previous findings (O'Sullivan, 2005; and Tsangaridou, 2002), which concluded that reflections on teacher beliefs and values can have an impact on their behaviors in the class. Also, Carr (2004) and Lunenberg et al. (2007) suggest the creation of a 'community of practice', which connects the pre-service teachers with practitioners, students, and the wider school communities.

In addition, teachers can also equip themselves with the competence to teach values through group discussions, reading books, and other forms of self-development activities in order to provide for what is lacking in the university education. This suggestion is in accordance with the findings of Berkowitz \& Bier (2005) which state that for a broader scope, values should not only be taught through class curriculum or programs but should also be instilled through all the experience gained during the certain levels of education.

The study conducted by Megler (2008) suggests that the training and development programs organized by the government (Teacher Professional Education/PPG) should provide an opportunity for prospective teachers to analyze and reflect on their own values. And according to Beavis (2004), this will make them be a moral guide for students. Therefore, teachers are required to become practitioners who continuously reflect on their own values and morals (Mergler, 2008). Also, O'Sullivan (2005) mention the fact that the reflections on teacher beliefs and values can have an impact on 
the teaching and practice in the classroom. To achieve this, the education process in LPTKs needs to be improved. Personal and social competencies, which are more related to values, need to get more attention alongside the other two ones, pedagogic and professional, which have already received serious attention.

\section{CONCLUSION}

In accordance with the research results and data analysis, this reseacrh draws four conclusions as follows: 1) The method for a teacher recognizes the values can be divided into two; those are recognizing the values through positive experience basedvalues, and recognizing the values through negative experience based-values. Related to this finding, there is a need to turn to a positive learning environment. Students have basic emotional needs which include the need to be loved, understood, considered valuable, respected, and safe both physically and psychologically. If the school climate supports these five needs, students will grow with the right values and vice versa. 2) The teachers from those two categories consider that the values are important factors to perform their duties. Since teacher is a profession which is holding values inside, personal values become a very important element in supporting the teachers' success in performing their duties. 3) The method of a teacher recognizing the values affects the method of teaching the values to the students. The teachers who recognize the values through positive experience based-values will teach the values to the students along with concerning the pedagogic principles, and vice versa. 4) The teachers' opinions reflect that the undergraduate program has not given yet enough preparation to them for implementing the values education at school. Their competence of teaching the values is mostly gained through activities outside the university programs, and through other training programs, both formal and informal ones, when they are already as a teacher. Furthermore, a systematic and measurable program to provide values education for teachers and prospective teachers is required. The results of this study showed that during their undergraduate education at the university, teachers lacked the knowledge and competencies to teach values to the students. In the Indonesian context, these problems need to be addressed carefully by both the government and the LPTK. The programs implemented should be carried out based on the needs of teachers, principals, and the community as a whole.

\section{ACKNOWLEDGEMENT}

The researchers thank the Directorate General of Research and Development Strengthening (Ministry of Research, Technology and Higher Education of Republic of Indonesia) for giving grant of research schema, Basic Research of Superior University (PDUPT), and also grant of Overseas Seminar Assistance (BSLN) as this paper has been presented at Brighton, United Kingdom.

\section{REFERENCES}

Abramauskienè, J. (2015). Būsimųų pradinių klasių mokytojų požiūris ì tautines vertybes. Pedagogika / Pedagogy. t. 119, Nr. 3, p. 147-159 / Vol. 119, No. 3, pp. 147$159,2015$. 
Arthur, J. (2003). Education with character: The moral economy of schooling. London: Routledge Falmer.

Arthur, J., Kristjánsson, K., Walker, D., Sanderse, W., \& Jones, C. (2015). Character education in UK schools research report. School of Education, University of Birmingham.

Banks, J., Cochran-Smith, M., Moll, L., Richet, A., Zeichner, K., LePage, P., DarlingHammond, L., Duffy, H., \& McDonald, M., (2005). Teaching diverse learners. In J. Bransford, L. DarlingHammond (Eds), Preparing teachers for a changing world'. San Francisco: Jossey-Bass.

Beavis, A. (2004). Why parents choose private or public schools. Research Developments, 12(12), 1-5.

Bennett, W. J., \& Delattre, E. J. (2011). Moral education in schools. In J. L. DeVitis, T. Yu (Eds.), Character and moral education: A reader (pp. 3-15). New York, NY: Peter Lang.

Benninga, J. S., Berkowitz, M. W., Kuehn, P., \& Smith, K. (2006). Character and academics: What good schools do. Phi Delta Kappan, 87(6), 448-452.

Berkowitz, M.W., \& Bier, M.C. (2005). The interpersonal roots of character education. In D.K. Lapsley \& F.C. Power (Eds.), Character psychology and character education (pp. 268-285). South Bend, IN: University of Notre Dame Press.

Brady, L. (2011). Teacher values and relationship: factors in values education. Australian Journal of Teacher Education, 36(2), 56-66. http://dx.doi.org/10.14221/ajte.2011v36n2.5

Bransford, J., Darling-Hammond, L., \& LePage, P. (2005). Introduction. In J. Bransford, L. Darling-Hammond (Eds), Preparing teachers for a changing world'. San Francisco: Jossey-Bass.

Brooks, B. D. \& McCarthy, P. J. (2001). Teaching the two Rs: Right and 'wrong. Business and Society Review, 68, 52-55.

Brown, H., Woods, A. M., Hirst, E. M., \& Griffith, D. H. (2006). The public construction of values in education.

Capel, S. (2015). Value orientations of student physical education teachers learning to teach on school-based initial teacher education courses in England. European Physical Education Review. 1-18. DOI: 10.1177/1356336X15596984

Carr, D. (2004). Moral values and the arts in environmental education: towards an ethics of aesthetic appreciation. Journal of Philosophy of Education, 38(2), 221-239.

Carr, D. (2008). Character education as the cultivation of virtues. In L. P. Nucci, D. Narvaez (Eds.), Handbook of moral and character education (pp. 99-116). New York, NY: Routledge. 
Chong, S. \& Cheah, H. M. (2009). A Values, skills and knowledge framework for initial teacher preparation programmes. Australian Journal of Teacher Education, 34(3), 1-17. http://dx.doi.org/10.14221/ajte.2009v34n3.1

Connors, L. (2002). The values that characterize public schooling: A Thermopylae well worth defending. In S. Pascoe (Eds.), Values in education (pp. 59-70). Canberra: Australian College of Educators.

Creswell, J. W. (2008). Educational research: Planning, conducting, and evaluating quantitative and qualitative research (3rd ed.). New Jersey: Pearson Prentice Hall.

Dalton, J. \& Crosby, P. (2010). How we teach character in college: A retrospective on some recent higher education initiatives that promote moral and civic learning. Journal of College and Character, 11(2), 13-17.

Darling-Hammond, L., \& Bransford, J. (Eds). (2005). Preparing teachers for a changing world: What teachers should learn and be able to do. CA: Jossey-Bass.

DEST. (2008). At the Heart of What We Do: Values Education at the Centre of Schooling - The Final Report of the Values Education Good Practice Schools Project Stage 2 August 2008. [Bereznicki, B., Brown, D., Toomey, R., \& Weston, J. (2008). At the heart of what we do: Values education at the Centre of schooling-the final report of the values education good practice schools project-stage 2. Carlton South Vic: Australian Government, Department of Education, Employment and Workplace Relations Curriculum Corporation.] Retrieved from (13 January, 2012), http://www.curriculum.edu.au/verve/_resources/VEGPSP-2_final_3.pdf.

Douglas, D. (2003). Grounded theories of management: A methodological review. Management Research News, 26(5), 44-52.

Eisner, E. W. (2002). The educational imagination: On the design and evaluation of school programs (3rd ed.) Upper Saddle, NJ: Merrill Prentice Hall.

Ferguson, A. (1999). Character goes back to school. Time, 153(20), 68-70.

Gellel, A. (2010). Teachers as key players in values education: Implications for teacher formation. In T. Lovat, R. Toomey, \& N. Clement (Eds.), international research handbook on values education and student wellbeing (pp. 163-176). Dordrecht: Springer.

Hadi, R. (2015). The integration of character values in the teaching of economics: A case of selected high schools in Banjarmasin. International Education Studies. 8(7), 1120. http://dx.doi.org/10.5539/ies.v8n7p11

Hattie, J. (2003, October). Teachers make a difference: What is the research evidence? Paper presented at the Australian Council for Educational Research Annual Conference on Building Teacher Quality, Melbourne, Australia.

Liamputtong, P. (2009). Qualitative research methods (3rd ed.). Melbourne: Oxford University Press. 
Lockwood, A. L. (2009). The case for character education: A developmental approach. New York, NY: Teachers College Press.

Lovat, T. (2007a). Synergies and balance between values education and quality teaching. Paper presented at the Moral Education and Australian Values Conference. [Lovat, T. J. (2010). Synergies and balance between values education and quality teaching. Educational Philosophy and Theory, 42(4), 489-500. https://doi.org/10.1111/j.1469-5812.2008.00469.x]Retrieved 28 November, 2010 from http://www.education.monash.edu/research/conferences/moral-education/index.html

Lovat, T. (2007b). Values education: The missing link in quality teaching and effective learning. In D. N. Aspin, J. D. Chapman (Eds.), Values education and lifelong learning: Principles, policies, programmes (pp. 199-210). Dordrecht: Springer Verlag.

Lovat, T., Clement, N., Dally, K., \& Toomey, R. (2010). Values education as holistic development for all sectors: researching for effective pedagogy. Oxford Review of Education, 36(6), 713-729.

Lovat, T., R., Dally, K., \& Clement, N. (2009). Project to test and measure the impact of values education on student effects and school ambience (Final Report). The University of Newcastle, Australia.

Lovat, T., Dally, K., Clement, N., \& Toomey, R. (2011). Values pedagogy and teacher education: re-conceiving the foundations. Australian Journal of Teacher Education, 36(7), 31-44.

Lunenberg, M., Korthagen, F., \& Swennen, A. (2007). The teacher educator as a role model. Teaching and Teacher Education, 23, 586-601.

McLaughlin, T., \& Halstead, M. (1999). Education in character and virtue. In T. McLaughlin, M. Halstead (Eds.), Education in morality (pp. 118-131). London: Routledge.

Mergler, A. (2008). Making the implicit explicit: Values and morals in queensland teacher education. Australian Journal of Teacher Education, 33(4), 1-10. http://dx.doi.org/10.14221/ajte.2008v33n4.1

Mergler, A. G., \& Spooner-Lane, R. (2012). What pre-service teachers need to know to be effective at values-based education. Australian Journal of Teacher Education, 37(8), 66-81. http://dx.doi.org/10.14221/ajte.2012v37n8.5

Metzger, S. A. \& Wu, M. (2008). Commercial teacher selection instruments: The validity of selecting teachers through beliefs, attitudes, and values. Review of Educational Research. December, 78(4), 921-940.

O'Sullivan, S. (2005). The soul of teaching: education teachers of character. Action in Teacher Education, 26(4), 3-9.

Purpel, D. E. (2011). The politics of character education. In J. L. DeVitis, T. Yu (Eds.), Character and moral education: A reader (pp. 43-52). New York, NY: Peter Lang. 
Salls, H. S. (2007). Character education: Transforming values into virtues. New York, NY: University Press of America.

Singh, A. (2011). Evaluating the impacts of value education: Some case studies. Internasional Journal of Educational Planning \& Administration, 1(1), 1-8.

Suyatno, Jumintono, Pambudi, D. I., Mardati, A., \& Wantini (2019). strategy of values education in Indonesia education system. International Journal of Instruction, 12(1), 607-624. https://doi.org/10.29333/iji.2019.12139a

Tillman, D. (2004). Living values education. Jakarta: Gramedia.

Tirri, K. (2010). Teacher values underlying professional ethics. In T. Lovat, R. Toomey, $\mathrm{N}$. Clement (Eds). International research handbook on values education and student wellbeing. Dordrecht: Springer.

Tsangaridou, N. (2002). Enacted pedagogical content knowledge in physical education: A case study of a prospective classroom teacher. European Physical Education Review $8(1), 21-35$.

Watt, H. M. G., \& Richardson, P. W. (2004, July). Self-concept of teaching ability and values for teaching: definition, measurement and relative influences on the choice of teaching as a career. Paper presented at the Third International Biennial SELF Research Conference. Berlin, Germany.

Willms, J. D. (2000). Monitoring school performance for 'standards-based' reform. Evaluation and Research in Education, 14, 237-253

Wren, T. (2008). Philosophical moorings. In L. P. Nucci, D. Narvaez (Eds.), Handbook of moral and character education (pp. 11-29). New York, NY: Routledge. 